\title{
Meanings of lone motherhood within a broader family context
}

\section{Vanessa May}

\begin{abstract}
In this paper, the theoretical approach to the concept of lone motherhood is adopted from 'new' family sociology where families are understood to be dynamic processes constituted by webs of relationships. I analyse life stories written by lone mothers in order to examine the meanings that they give to their lone motherhood in relation to their larger family context. This approach reveals that, along with the concept 'family', the category 'lone motherhood' can be questioned. The life stories show that as with all families, the representations of 'the lone mother family' vary. Lone motherhood emerges less as a distinct family form and more as an experience coloured by the lone mother's position in a web of family relationships, as well as her place in her broader personal, social and historical context.
\end{abstract}

\section{Introduction}

The recent 'narrative turn' in the social sciences is reflected in how contemporary family sociologists approach their subject. Examining the social construction of 'family', researchers now listen to the stories people tell of family life and focus on everyday actors' own definitions of 'family', (eg, Stacey, 1991). There is also an increasing understanding of the dynamic nature of family life. Rather than viewing families as static entities defined by family structure, recent studies have examined family life as a process and 'family' as a web of relationships (eg, Smart and Neale, 1999). The focus is on individuals doing and being families (Gubrium and Holstein, 1990; Morgan, 1996).

However, despite this reinvigorated theoretical focus on 'family', a similar deconstruction of the concept 'lone motherhood' has been lacking. This paper takes on board the theoretical challenges posed by the 'new' family sociology to examine how lone mothers describe and define their families in their written life stories. Furthermore, in order to grasp the dynamic nature of family life, the focus is on family relationships over time. 


\section{Dynamic webs of family relationships}

Researchers have for long now viewed 'the family' as a misleading concept because it implies a firm and unchanging reality (eg, Thorne, 1982). The term is no longer used as a noun, but rather as an adjective or even a verb, with families viewed not as a thing, but as something that people do through everyday practices (Gubrium and Holstein, 1990; Morgan, 1996; Morgan, 1999).

Family theory no longer presents families as fashioned around a set structure but rather as complex webs of family relationships that constantly undergo changes (Stacey, 1991; Smart and Neale, 1999). This processual nature of families is captured by the concept of multidimensional developmental pathways, which depict how an individual negotiates her way through various social structures (Bernardes, 1986). A number of different pathways can be envisaged, such as an individual family pathway. As an individual through the course of her life is linked to other individuals, their family pathways intertwine, and separate, creating a rich tapestry of interlinked pathways.

However, the issue of family form seems virtually unavoidable when examining lone motherhood. It is 'the lone-mother family' whose structure is scrutinised by the media, politicians and scientists alike (cf. VanEvery, 1999). It appears that lone motherhood is particularly resistant to the efforts of family theorists to 'deconstruct' the concept of family. Researchers tend to employ lone motherhood as a relatively unproblematic category, although the meanings it is given can vary widely from that of a social problem (eg, Popenoe, 1993) to an expression of women's independence (eg, Bock, 2000).

In seeking to provide a fresh perspective on lone motherhood, I examine the phenomenon from the inside so to speak in order to gain an understanding of the place it is given by lone mothers themselves in their life stories. However, rather than taking lone motherhood as the starting point for analysis, I focus on how the women describe the course that their family pathways have taken and on how they situate their lone motherhood within them.

\section{The study}

The life story material analysed in this article consists of seventeen life stories written by Finnish women who have experienced lone motherhood. The life stories are part of a larger life story collection collected in 1995 under the project name Kvinnoliv $i$ Svenskfinland (Women's lives in Swedish-speaking Finland) by the Institute of Women's Studies at Åbo Akademi University in Finland. Potential contributors were urged to write their life stories in their own words, focusing on what mattered in their lives - thus they were not asked to write about any specific topics such as family life. Data such as these are ideal for studying how individuals place one family phase such as lone motherhood within a broader individual context. 
Of the 130 written life stories received by the project, I chose the ones written by women who said that they at some point in their lives had been lone mothers, seventeen in all. The oldest narrator in my material was born in the 1910s and the youngest in the 1960s. The life stories cover experiences of lone motherhood from the 1940s to 1995 . There are all types of lone mother in my material: women who have alone had children, widows, and divorced women. The writers' social and educational backgrounds vary from a poor agrarian background with only a basic education to a middle-class background with a university education. All of the narrators have been employed either in agriculture or in the labour market for most of their adult lives, as has become the norm for women in Finland (Julkunen, 1999).

Life stories are generally expected to express 'common narrative themes concerning the author as a person', to convey the 'key moments' in the narrator's life and to give these 'personal and sociological meaning' (Denzin, 1989b: 68). Life story narrators tend to rely on narrative conventions and base their life stories on culturally shared genres, and narratives (Riessman, 1993; Vilkko, 1997).

In this article, each life story is analysed as a whole, and the narrative of lone motherhood is related to this whole (cf. Riessman, 1993: 4). In order to determine the meaning the narrators are attempting to convey, both narrative structure and content are analysed. Narrators communicate with their audience on several levels and tacitly refer to more than is explicitly stated, for example, through the structure of the story and the way the story is told (Ochberg, 1996; Denzin, 1989a: 11).

In order to uncover the narrative structure of a life story, I focus on the pace and thickness of narrative. The pace of a narrative is seldom constant, as narrators decelerate and accelerate the tempo of the narrative as a way of foregrounding and emphasising certain episodes (Rimmon-Kenan, 1983: 53). Related concepts are those of narrative thickness and narrative thinness (Hyvärinen, 1998). A thin narrative glosses over events, whereas thick narratives provide detailed descriptive or evaluative information. In the analysis, I focus on which episodes the narrators foreground and what meaning they wish to convey through doing so.

When analysing the content of the life stories, I focus on the meanings the narrators assign to their family relationships (cf. Holstein and Gubrium, 2000: $29,47)$. I also examine how various family members are portrayed and how important a role they play in the life story. Lastly, I analyse how lone motherhood is positioned within this web of relationships.

\section{Mapping the constructions of family}

Four categories emerge from the life stories, based on how the narrators construct their families. The first category consists of life stories where the 
narrator's parents emerge as the dominant characters throughout the narrator's life. The narrators interpret all other aspects of their lives in relation to this family relationship. In the second category, the narrators depict their family lives in stages by drawing clear boundaries between their different 'families', each of them appearing separately in the narrative. The third category contains life stories where the narrative transitions between different families are smooth and gradual. In these life stories, the narrator's various families overlap. In the life stories comprising the last category, the narrators give clear precedence to a particular issue that functions as an interpretive tool through which the life story is narrated. These four categories are of course Weberian ideal types and no life story exhibits characteristics of only one type. It is important to note that these are not categories of lone motherhood, but categories of family. As explained above, this is a study of lone motherhood within a family context, where the context plays an important role in explaining the lone motherhood.

Below, I illustrate each category with an example from both an older narrator (born before the 1940s) and a younger narrator (born during or after the 1940s) to exemplify how understandings of family relationships have changed in the latter half of the Twentieth century (cf. May, 2003).

\section{Overshadowing parental influence}

In the life stories that comprise the first category, the key figures are the narrator's parents. The narrators focus on how their parents have determined their life and exerted a strong practical or emotional influence. The two life stories used to exemplify this category are those of Sofia and Barbro. ${ }^{1}$ Both grow up in the countryside - Sofia in the 1910s and Barbro in the 1940s - and move to an urban setting as adults.

Sofia and Barbro both depict their fathers as the central characters in their lives. They employ narrative strategies such as foregrounding their fathers by for example slowing down the pace of the narrative (Rimmon-Kenan, 1983: 53) and providing a 'thick' account (Hyvärinen, 1998) of how their fathers have impacted upon their lives.

Sofia tells how her father irrevocably shaped her life when he declined to allow Sofia to continue with her education. She believes that this decision has had negative repercussions when her life did not go according to plan and she found herself a divorced mother of two:

My marriage was not the life insurance my father had thought it would be when he did not want me to continue at school even though I had the chance. It is a waste of money to educate girls because they get married and are supported was his argument when the headmaster tried to persuade him. ${ }^{2}$ 
In the early twentieth century, few working-class families could afford to educate all, if any, of their children, and the education of boys was generally deemed more important because they would one day be supporting a family (cf. Aromaa, 1990: 165). However, as in Sofia's case, also women could be faced with this responsibility. This meant that Sofia had to work extremely hard but she exhibits pride at her success in supporting her children. She thus tells a narrative of hardship, of triumph through adversity, a popular type of story in Finland, especially among older generations (cf. Roos, 1987; Vilkko, 1997).

Barbro does not describe her father as having the same direct influence on her educational and career choices, perhaps because Barbro is of a younger generation and grew up at a time when education was becoming more widely available to women. In Barbro's case, her father's influence is of a psychological nature. His continuous disapproval of Barbro during her childhood 'has led to me being unable to assert myself in private'.

Compared to the thick narrative descriptions of their relationships with their fathers, both Sofia and Barbro provide thin narratives of their adult relationships. The following quote is all Sofia says about her marriage:

On [date] I married and my first son was born the next year. We lived in [place name] and my husband did his military service. Then I gave birth to [daughter], [year], and [son], [year]. My pregnancies were miserable because I was ill all the time, but the deliveries were in corresponding degree easy. When [third child] was born on [date] my husband had been drafted, but the Winter War had not yet begun.

Sofia never describes the relationship between herself and her husband. Indeed, she tells the story of her marriage not through her husband's presence but through his absences.

Barbro also offers the reader little information on her husband or on their relationship. She relates almost everything in her life back to her upbringing and her parents' influence on her life. For example, she explains her decision to marry by relating it to her parents' objections to cohabitation:

After three months of cohabiting we (I) decided to get married - in order to calm my parents.

Similarly, after her eventual divorce, Barbro provides only the thinnest of descriptions of her subsequent relationship to the father of her child. She merely says that when he demanded an abortion, 'I told him to get lost and managed everything on my own'. It is at this point that the narrative changes in character. From being a downtrodden daughter and wife, Barbro developes into an independent woman. Barbro's life story resembles a Bildungsroman, a story of awakening and enlightenment (Felski, 1986: 137-8). In such stories, the female protagonist comes to question and reject generally accepted 
life-style choices, such as having children in a (heterosexual) relationship. Barbro's life story reflects not only the increased opportunities that have become available to younger generations of women but also her class. Educated middle-class women in Finland are more prone to question norms and to tell non-normative accounts (Nätkin, 1997: 211).

Sofia and Barbro narrate also their (lone) motherhood in relation to their family of origin. Sofia implicitly lays the blame of her divorce on her brothers, who upon learning of her husband's affair did nothing because they 'thought it was my family's business and that they should not get involved'. However, she also recounts how her sisters provided invaluable practical support, with one of her sisters becoming a 'second mother' to her children. Barbro depicts her lone motherhood in relation to the lack of support from her parents:

My so-called friends and family [...] did not have time for me. There I sat alone.

Both also convey to the reader that they have consciously treated their children differently to how they themselves were brought up. Sofia focuses on how she made sure that her children received an education despite the family's extremely tight finances, while Barbro points out that

I have tried to avoid the mistakes that my parents made with me. I react quickly if my daughter has problems. We talk and I keep her informed. She gets to know WHY, which I never did. With my father it was always just prohibitions....

Although Sofia and Barbro provide widely different accounts of lone motherhood, both recount their lives in relation to their family of origin. They do not present the (missing) father of their child as central to how they interpret their lone motherhood. Rather, it is their relationship with their own father and how this has shaped them that provides the interpretive context to their representations of lone motherhood.

\section{The adult relationship}

In the life stories comprising this second category one adult relationship emerges as the most important. The two case examples in this category are the life stories of Sylvia and Ellen. Sylvia is an urban, middle-class woman and her life story spans from the 1910s to the 1990s. Ellen's life story is also set in the context of urban middle-class life, and is mostly centred around her experiences in the 1970s and 1980s. These two life stories are similar in how the narrators place the main emphasis on adult romantic relationships, with a particular focus on one key relationship. 
Sylvia focuses on her first sexual relationship with 'the love of my life', a married man. In Ellen's life story, the key relationship is the one she has with her second husband. Both describe these relationships in terms of fate and irresistible attraction. Sylvia tells of their first meeting by saying 'my fate was sealed for many years to come', while Ellen describes how 'I fell suddenly and head over heels in love. And there was nothing more to do.'

These relationships also bring trauma into the lives of the narrators. Sylvia's passionate affair ends when she becomes pregnant: 'What happened was what usually happens in such cases: tears, recriminations, irritation and the awful feeling of being left alone'. Sylvia quickly realises that she will be bringing up her child alone. Ellen describes in detail the physical and emotional abuse she suffered at the hands of her second husband. She explains how she eventually left her husband in order to protect her newborn son:

And last but not least: would [my son] be spared? Think if he would also become the target of the same aggression that was directed at me? Was this not in fact probable?

Compared to how they narrate this one key relationship, both Sylvia and Ellen provide thin descriptions of their other adult relationships. Sylvia sums up her two subsequent marriages, in-between which she is a widow with two children, in a paragraph each. Ellen also provides thin narratives of her first and third marriages.

Sylvia and Ellen also present relatively thin descriptions of their relationships with their children and of their times as lone mothers. Furthermore, they interpret their lone motherhood in relation to their relationship with the father of their child. In contrast to the passion Sylvia experienced with her lover and the emotional security she found with her first husband, she depicts her times as a lone mother in desolate terms.

I have never really got over the grief and longing, and even today it feels difficult to think of the years that followed. The most difficult thing was to see how [my son] missed his father.

For Ellen, becoming a lone mother signified the end of a destructive relationship and is thus imbued with positive meaning: 'When [my son and I] moved I had at last put a stop to the sorrows and worries of before.'

These are perhaps closest to what is generally expected of a story of lone motherhood, where the meanings of lone motherhood are derived in relation to the mother's relationship with the father.

\section{Overlapping families}

The life stories in this third category differ from the ones in the first two in that no single relationship gains centre-stage but rather each phase in life and 
each 'family' receives equal attention. Furthermore, the narrators do not compartmentalise their families but rather create narrative overlap between their different family relationships. The narrator typically situates herself in the middle of her extended family and adds new family members to this existing web, while old family members do not necessarily fall away even after death. Nevertheless, for each stage in life there is one key relationship.

Maria's life story is the first example. She is born in the 1910s and grows up in a poor agrarian family. Katarina is the youngest life story writer, born in the 1960s. She grows up in an urban middle-class family.

In both life stories, the key relationship in the narrator's childhood is described as idyllic. Maria details her close and warm relationship with her parents: 'We children were the most important thing in mother's and father's life and it is true that we learnt to obey and to help from a young age, but we never lacked anything'. Maria's memory of life in the country-side in the early twentieth century differs from how it is generally depicted, as a life of hard work and toil with little energy left over for emotions and affection (cf. Roos, 1987). Maria emphasises how her parents, though poor and hard-working, expressed their love for their children and cared for not only their physical survival, but also their happiness.

In Katarina's case, it is not her parents but her nanny who emerges as the key person during her early years, providing her with a blissful childhood, 'full of caring, flowering apple trees and lemonade on the grass'. Katarina's parents on the other hand emerge as distant figures, "[a]t home there were never any hugs, never any warm emotions, I yearned for affection and this yearning remains today'. Katarina's life story follows the form of a tragedy, where the protagonist experiences a downfall and remains isolated from the world (Frye, 1952: 37, 39). The same lack of warmth that characterises Katarina's childhood relationship with her parents continues throughout her other relationships. Katarina portrays herself as also alienated from the materialistic values of modern life, expressing a wish to escape to a life near nature.

Both Maria and Katarina keep their families of origin present in their life stories even after they have left home and had families of their own. Maria describes close links between herself and her parents, and her siblings. For example, she returns to live with her parents when her husband is sent to the front during the Second World War and again when her mother is terminally ill. Maria tells how after the death of her mother, she maintained even closer relationships with her father and siblings. Maria also describes the warm and affectionate relationship she enjoyed with her husband. This idyllic existence is shattered when Maria's father and husband die in quick succession -

And yet life has to go on somehow. [...] But it was so hard to go on living. How could I be my children's only support and help, when they were to be equipped for their lives that none of us knew anything about. 
It is at this point that Maria's life story gains tragic overtones, never again fully shedding this sense of anguish.

Katarina also includes her parents in the story of her adult life. For example, they offer their support when Katarina finds herself pregnant and the father of her child wants an abortion:

From the first day of my pregnancy I was firmly determined to give birth to my child despite pressures from the father-to-be. My parents gave me their full support as did, surprisingly enough, the future grandparents from the father's side.

Beyond this, Katarina does not comment on whether the quality of her relationship with her parents had improved since her childhood. Katarina's parents died not many years after her child was born, thus removing the main source of support Katarina was relying on and leaving Katarina yet again alienated from the world. Tellingly, she compares her own situation (alone with a child) with that of her sister, who lives with her 'little, snug, happy family' consisting of her husband and children. Katarina thus indicates that her parents' death has left her feeling isolated and unprotected.

In both Maria's and Katarina's life stories the dead are almost as important as the living. Indeed, Maria continues to situate herself within this web of relationships even after the other members have died:

Everything was fine except for the weekends. Then the loneliness was there like a ghost and I mostly wandered to the cemetery. This was where the ones I missed so were.

This construction of family is best captured by Urry's (1990) concept of 'imagined co-presence' where family members who are dead or geographically distant are still part of an 'imagined family'.

During their time as lone mothers, the key relationships Maria and Katarina have are those with their children. Maria describes the practical and emotional support that her children have offered her ever since, while Katarina says:

My child has given me an inner strength and that strength is still there even though he is becoming older and needs me less. We love each other very much.

Maria narrates her second marriage in relation to her children and her responsibilities as a mother 'I was so deeply grateful that it looked as though my children were going to manage, and that my task appeared to be accomplished'. But her children do not disappear from the narrative at this point, as Maria intertwines tales from her unhappy second marriage with happier memories of her close ties to her adult children and their families. 
Maria and Katarina's descriptions of lone motherhood are the polar opposite of the isolated lone-mother family as portrayed by studies that focus on family structure. Both portray themselves as embedded in all their families simultaneously, providing narrative overlap for their various family relationships. The narrators can be seen moving on their individual pathways through several families that are parallel and interconnected (cf. Bernardes, 1986). What many sociologists would define as separate families are merged into one family in the life story, a family that expands and contracts through the writer's life course. Lone motherhood emerges as one aspect of family life and only becomes more palpable when this extended network of family relationships shrinks. Thus it is not so much the missing father who leaves the narrators alone and isolated, but the loss of other key relationships. It is this that gives meaning to the narrators' experiences of lone motherhood.

\section{Family as secondary}

The last category consists of life stories that are constructed around some other issue than family. Family life serves to highlight this main point in the life story. Emma, born in the 1910s, and Ulla, born in the 1940s, both focus on the issue of gender.

The main focus of Emma's life story is on how gender inequality impacted upon her as a divorced mother in the 1940s and 1950s. She notes bitterly how she as a woman has been powerless and without a voice in her local community - whereas her young son is treated by others as the head of the family purely on the basis of his gender. Of one such incident she comments: 'I could barely believe my ears! This five-year-old was a man [in the eyes of others]! He had succeeded in what had seemed impossible for me' (emphases in original). Emma's disbelief perhaps stems from the fact that the 'normal' family hierarchy based on age was in her case overridden by gender, because her son 'was a MAN!'. Emma laments that when dealing with her family, others 'only turned to my son' (emphasis in original), whereas she was 'only a minor figure'. Emma's life story fits the description of a tragedy, telling the story of alienation. Emma compounds this feeling of alienation throughout her life story by emphasising the countless ways in which she differs from the people in her local community and how isolated she is because of this.

Ulla also constructs gender as the central issue in her life story. But unlike Emma, she finds a way to escape the restrictions that her gender potentially places upon her, perhaps because she is of a younger generation. Ulla contrasts herself with her mother, who was trapped in an unhappy marriage with Ulla's father:

There were innumerable occasions when I thought that were I in my mother's situation I would take the children and move away, and get a 
divorce. But mother did not have the financial prerequisites to support a family of four.

Ulla says this made her determined from a young age not to fall into the same trap, but to always make sure she was financially independent and thus in control of her own destiny. She decided that 'I will get an occupation that I can support myself with'.

Emma and Ulla provide scant information on their marriages and husbands. Perhaps this is because the main point of their life story, the effect of gender in their lives, only becomes fully exposed once they stray from the prescribed path that women of their generations have been expected to follow. In both life stories the narrative thickens when the narrators discuss the "nonnormative' aspects of their lives. Thus after a thin narration of her marriage, Ulla decelerates the pace of the narrative when she explains her decision to divorce her husband. She ties in this decision with the central point of her life story, the importance of remaining financially independent in marriage:

I was grateful that I was in a situation where divorce was possible practically and financially. I had a job with a good salary and managed well financially.

Unlike her mother, Ulla 'dared take the step to divorce, because I had a secure and well-paying job'. Like other well-educated women life story writers in contemporary Finland, Ulla seems able to portray her non-normative decision to divorce as an enlightened one (cf. Nätkin, 1997: 211).

The narrators use their experiences to illuminate the overriding substantive focus of the life story. Thus when writing about their time as a lone mother, the narrators focus on the issue of gender rather than on lone motherhood as such. Lone motherhood for them means being perceived by others as a woman bringing up her children without a man and hence brings the issue of gender (in)equality to the fore. It is around this aspect that they construct the meaning of their experiences. Thus in Emma's case, lone motherhood is problematic because she is a woman, whereas for Ulla lone motherhood poses no such problems because she has managed to avoid the potential pitfalls that her gender has placed before her. The fact that Emma seems burdened by her gender, whereas Ulla only sees it as a potential obstacle in life can at least partly be attributed to changes in women's positions in Finnish society. Ulla is among the first generation of women to fully draw advantage of women's advances in education, their improved position in the labour market, and their increased autonomy within and outside families (Julkunen, 1994; Markkola, 1990).

\section{Conclusions}

In this paper, I have approached the deconstruction of the concept 'lone motherhood' by examining how lone mothers plot their family pathways over time 
and how they place lone motherhood within these. The life stories fell into four categories based on how the narrators constructed their family relationships. In each category, different relationships became key. In the first category, it was a childhood relationship whereas in the second category it was the narrator's relationship with the father of her children. In the third category, the whole network of family relationships gained centre-stage. The life stories in the last category were structured not so much around specific relationships but around a particular issue, namely gender (in)equality. The four categories illustrated that family relationships can be constructed differently, and that consequently the meanings assigned to lone motherhood also vary.

Most importantly, the narrators tended not to construct 'lone mother families' but rather webs of relationships with varying emphases on different relationships or stages of life. Lone motherhood tended to be only one aspect of these family pathways and thus emerged less as a distinct family form and more as an experience coloured by the lone mother's place in a network of relationships, as well as her place in her broader personal, social and historical context.

The life stories illustrated the varying ways in which lone mothers can position themselves, consequently creating a kaleidoscope of images of lone motherhood. A lone mother can appear as a daughter doing her best to avoid the mistakes her parents made with her, as a heart-broken woman learning to live without the father of her children, as a member of a large family network who falls upon difficult times when this network shrinks, or as a woman in a maledominated society whose lone motherhood highlights existing gender inequalities. These images help deconstruct lone motherhood as it tends to be viewed: from the outside and as a unitary category of women defined by their lack of a male partner.

A focus on relationships and family networks that change over time rather than on family form therefore has consequences for how 'lone motherhood' is conceptualised. It draws attention to how interpreting the meaning of 'lone motherhood' requires contextualization. Lone-mother families tend to be viewed as 'less than' families, as families that are lacking a father. In contrast, this study has shown that lone mothers construct their families in more complex ways and that their families are not necessarily characterised by the lack of a male partner. 'Lone motherhood' derives its meaning from a variety of relationships and contexts.

Whether lone mothers are studied as lone mothers or whether the focus is on lone motherhood as part of a larger context has real consequences with regards to research outcomes and the effect it has on the people who are the focus of study. The first approach can easily lead to the labeling of lone mothers and lone motherhood as problematic, whereas the contextual approach perhaps guides our analytical gaze to issues such as gender inequality and deficiencies in family policy in order to explain the experiences of lone mothers. Thus, just as one has to be cautious when using the 
concept 'family', it is important to examine and question the category 'lone motherhood'.

\section{Acknowledgement}

I am indebted to Jacqueline Adams for her helpful comments on earlier versions of this paper.

\section{Notes}

1 I have given the narrators pseudonyms in order to protect their anonymity.

2 The quotations from the life stories are my translations from the Swedish originals.

\section{References}

Aromaa, V., (1990), 'Tyttöikä - tuulenpyörre ja tosipaikka', in Immonen, K. (ed.), Naisen elämä. Mistä on pienet tytöt tehty, mistä tyttöjen äidit, Keuruu: Otava.

Bernardes, J., (1986), 'Multidimensional developmental pathways: A proposal to facilitate the conceptualisation of "family", The Sociological Review, 34: 590-610.

Bock, J., (2000), 'Doing the right thing? Single mothers by choice and the struggle for legitimacy', Gender and Society, 14: 62-86.

Denzin, N.K., (1989a), Interpretive Interactionism, Newbury Park, CA: Sage.

Denzin, N.K., (1989b), Interpretive Biography, Newbury Park, CA: Sage.

Felski, R., (1986), 'The novel of self-discovery: A necessary fiction?', Southern Review, 19: 131-148.

Frye, N., (1957), Anatomy of criticism: Four essays, London: Penguin.

Gubrium, J.F. and Holstein, J.A., (1990), What is family?, Mountain View, CA: Mayfield.

Holstein, J.A. and Gubrium, J.F., (2000), Constructing the life course ( $2^{\text {nd }}$ edition, New York: General Hall.

Hyvärinen, M., (1998), 'Thick and thin narratives: Thickness of description, expectation, and causality', Cultural Studies: A Research Volume, 3: 149-174.

Julkunen, R., (1994), 'Suomalainen sukupuolimalli - 1960-luku käänteenä', in Anttonen, A., Henriksson, L. and Nätkin, R. (eds), Naisten hyvinvointivaltio, Tampere: Vastapaino.

Julkunen, R., (1999), 'Gender, Work, Welfare State', in Lipponen, P. and Setälä, P., (eds), Women in Finland, Helsinki: Otava.

Markkola, P., (1990), 'Pirtissä ja pellolla, kotona ja konttorissa', in Immonen, K., (ed.), Naisen elämä. Mistä on pienet tytöt tehty, mistä tyttöjen äidit, Keuruu: Otava.

May, V., (2003), 'Lone motherhood past and present: The life stories of Finnish lone mothers', Nordic Journal of Women's Studies, 11: 27-39.

Morgan, D.H.J., (1996), Family connections: An introduction to family studies, London: Polity Press.

Morgan, D.H.J., (1999), 'Risk and family practices: Accounting for change and fluidity in family life', in Smart, C. and Silva, E.B., (eds), New families?, London: Sage. 
Nätkin, R., (1997), Kamppailu suomalaisesta äitiydestä. Maternalismi, väestöpolitiikka ja naisten kertomukset, Tampere: Gaudeamus.

Ochberg, R.L., (1996), 'Interpreting life stories', in Josselson, R., (ed.), Ethics and process in the narrative study of lives, Thousand Oaks: Sage.

Popenoe, D., (1993), 'American family decline, 1960-1990: A review and appraisal', Journal of Marriage and the Family, 55: 527-555.

Riessman, C.K., (1993), Narrative analysis, Newbury Park, CA: Sage.

Rimmon-Kenan, S., (1983), Narrative fiction: Contemporary poetics, London and New York: Methuen.

Roos, J.P., (1987), Suomalainen elämä: Tutkimus tavallisten suomalaisten elämäkerroista, Helsinki: Suomalaisen Kirjallisuuden Seura.

Smart, C. and Neale, B., (1999), Family fragments?, Cambridge: Polity Press.

Stacey, J., (1991), Brave new families: Stories of domestic upheaval in late Twentieth century America, New York: Basic Books.

Thorne, B., (1982), 'Feminist rethinking of family: An overview', in Thorne, B. and Yalom, M., (eds), Rethinking the family: Some feminist questions, New York: Longman.

Vilkko, A., (1997), Omaelämäkerta kohtaamispaikkana. Naisen elämän kerronta ja luenta, Helsinki: Suomalaisen Kirjallisuuden Seura.

Urry, J., (1990), 'Time and space in Giddens' social theory', in Bryant, C.G.A. and Jary, D., (eds), Giddens' theory of structuration: A critical appreciation, London: Routledge.

VanEvery, J., (1999), 'From modern nuclear family households to postmodern diversity? The sociological construction of "families" ', in Jagger, G. and Wright, C., (eds), Changing Family Values, London and New York: Routledge. 